\title{
Altitudinal gradients in Magellanic sub-Antarctic lagoons: the effect of elevation on freshwater macroinvertebrate diversity and distribution
}

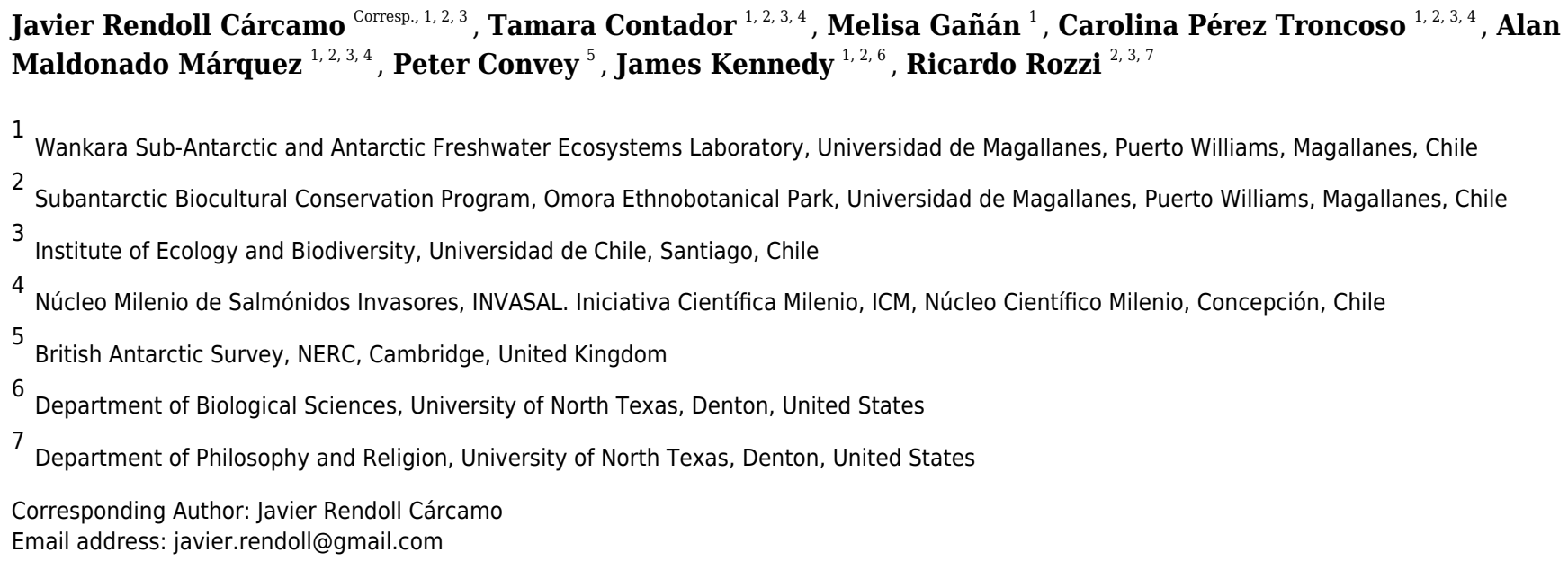

Background. The study of altitudinal gradients provides insights about species diversity, distribution patterns and related drivers. The Magellanic sub-Antarctic ecoregion has a steep elevational gradient, peaking at around $1000 \mathrm{~m}$ a.s.l., and marked changes in temperature and landscape composition can be observed over relatively short distances. Methods. This study assessed freshwater macroinvertebrate diversity associated with lakes and ponds along the altitudinal gradient of a Magellanic sub-Antarctic watershed. Results. A monotonic decline in species richness was observed with increasing elevation, with simpler and more even community composition at higher altitude. This pattern differs from the mid-peak trend found in streams of the same watershed. Functional feeding group structure also diminished with increasing elevation. Discussion. The study provides a descriptive baseline of macroinvertebrate community structure associated with lentic freshwater ecosystems in the Magellanic sub-Antarctic ecoregion, and confirms that elevation has substantial effects on community structure, function and environmental features, even in these relatively low elevation mountain ranges. The harsh environmental conditions of this ecoregion increase freshwater macroinvertebrate development time, as well as decreasing habitat availability and food supply, supporting simple but well adapted communities. In conjunction with previous research, this study provides a watershed-scale platform of information underpinning future long-term research in the region. 
1 ALTITUDINAL GRADIENTS IN MAGELLANIC SUB-

2 ANTARCTIC LAGOONS: THE EFFECT OF ELEVATION

3 ON FRESHWATER MACROINVERTEBRATE

4 DIVERSITY AND DISTRIBUTION

5 Javier Rendoll Cárcamo ${ }^{1,2,3}$, Tamara Contador ${ }^{1,2,3,4}$, Melisa Gañán ${ }^{1}$, Carolina Pérez

6 Troncoso $^{1,2,3,4}$, Alan Maldonado Márquez ${ }^{1,2,3,4}$, Peter Convey ${ }^{5}$, James Kennedy ${ }^{1,2,6}$, Ricardo

7 Rozzi ${ }^{2,3,7}$

8

9

1 Wankara Sub-Antarctic and Antarctic Freshwater Ecosystems Laboratory, Universidad de Magallanes, Puerto Williams, Chile

2 Subantarctic Biocultural Conservation Program, Omora Ethnobotanical Park, Universidad de Magallanes, Punta Arenas, Chile

3 Institute of Ecology and Biodiversity, Universidad de Chile, Santiago, Chile

4 Núcleo Milenio de Salmónidos Invasores, INVASAL. Iniciativa Científica Milenio, ICM, Núcleo Científico Milenio, Concepción, Chile

5 British Antarctic Survey, NERC, Cambridge, United Kingdom

6 Department of Biological Sciences, University of North Texas, Denton, USA

7 Department of Philosophy and Religion, University of North Texas, Denton, USA

Corresponding Author:

Javier Rendoll Cárcamo ${ }^{1,2,3}$

Teniente Muñoz 166, Puerto Williams, Antarctic Province, 6350000, Chile

Email address: javier.rendoll@gmail.com

\section{ABSTRACT}

Background. The study of altitudinal gradients provides insights about species diversity, distribution patterns and related drivers. The Magellanic sub-Antarctic ecoregion has a steep elevational gradient, peaking at around $1000 \mathrm{~m}$ a.s.1., and marked changes in temperature and landscape composition can be observed over relatively short distances.

Methods. This study assessed freshwater macroinvertebrate diversity associated with lakes and ponds along the altitudinal gradient of a Magellanic sub-Antarctic watershed.

Results. A monotonic decline in species richness was observed with increasing elevation, with simpler and more even community composition at higher altitude. This pattern differs from the mid-peak trend found in streams of the same watershed. Functional feeding group structure also diminished with increasing elevation.

Discussion. The study provides a descriptive baseline of macroinvertebrate community structure associated with lentic freshwater ecosystems in the Magellanic sub-Antarctic ecoregion, and confirms that elevation has substantial effects on community structure, function and environmental features, even in these relatively low elevation mountain ranges. The harsh environmental conditions of this ecoregion increase freshwater macroinvertebrate development time, as well as decreasing habitat availability and food supply, supporting simple but well 
39

40

41

42

43

44

45

46

47

48

49

50

51

52

53

54

55

56

57

58

59

60

61

62

63

64

65

66

67

68

69

70

71

72

73

74

75

76

77

78

adapted communities. In conjunction with previous research, this study provides a watershedscale platform of information underpinning future long-term research in the region.

\section{INTRODUCTION}

Since the times of the early naturalists such as Linnaeus, Humboldt, Darwin and Wallace, understanding how living organisms distribute and change along spatial gradients has been key for the development of theories about their origins and diversification (Lomolino 2001). From the wide spectrum of related variables, temperature is one of the most studied drivers of biodiversity richness and distribution (de Mendoza \& Catalán 2010, McCain \& Grytnes 2010). Air temperature predictably decreases as elevation increases, and at the same time regulates water temperature, ice and snow cover (Čiamporová-Zatovičová et al. 2010). In particular, latitudinal and elevational gradients can be considered analogues in terms of associated environmental clines and ecological features (Bozinovic, Calosi \& Spicer 2011, Rahbek 1995). In this context, faunal (and floral) research along elevational gradients is of critical importance in the study of global biodiversity drivers (McCain \& Grytnes 2010).

Increasing anthropogenic impact on the environment can significantly alter thermal regimes of freshwater ecosystems (Bates et al. 2008), threatening their biota (Millenium Ecosystem Assessment 2005). It is estimated that at least 126,000 invertebrate species inhabit freshwater ecosystems (Balian et al. 2008), of which between 10 and $15 \%$ are threatened by extinction or are already extinct (Vörösmarty et al. 2010). Understanding invertebrate sensitivity to ecological changes is of great importance, and these organisms have proven to be useful bioindicators (Kremen et al. 1993). Environmental temperature influences distribution, fitness, physiology and, ultimately, the survival of invertebrates (Boggs 2016), and research into its influence is a priority to underpin conservation and management strategies (Contador, Kennedy \& Rozzi 2012).

Southern South American ecosystems were strongly influenced by ice sheet expansion leading up to the Last Glacial Maximum (23,000 - 19,000 years before present), resulting in a heterogeneous and diverse mosaic of contemporary habitats (Hulton et al. 2002, Glasser et al. 2008). Glacial erosion shaped numerous archipelagos, mountain ranges and valleys, across numerous watersheds. In addition, the land:ocean ratio in the $40-60^{\circ} \mathrm{S}$ latitude belt is about 2:98, compared to 54:46 at equivalent latitudes in the Northern Hemisphere, supporting oceanic buffered climatic conditions (Rozzi et al. 2012). The Magellanic sub-Antarctic ecoregion lies between $47-56^{\circ} \mathrm{S}$, and is an area characterized by low altitude mountainous terrain $(\sim 1000 \mathrm{~m}$ a.s.1.), with short, steep and marked environmental gradients (Contador et al. 2015). In addition, the buffering effect of the ocean on temperature reduces drastically with elevation, which decreases by approximately $1^{\circ} \mathrm{C}$ for each $100 \mathrm{~m}$ increase in elevation (Contador et al. 2015, Méndez, Rozzi \& Cavieres 2013). While this ecoregion is considered one of the last pristine areas left in the world (Mittermeier et al. 2003), it is not free from the effects of global environmental change, massive tourism and introduced species (Rozzi et al. 2012). 
79

80

81

82

83

84

85

86

87

88

89

90

91

92

93

94

95

96

97

98

99

100

101

102

103

104

105

106

107

108

109

110

111

112

113

114

115

116

117

118

The freshwater macroinvertebrate species found within this ecoregion are highly endemic and well adapted to the cold-temperate weather conditions (e.g. through demonstrating variable voltinism patterns and physiological optima) (Contador et al. 2014, Contador \& Kennedy 2016). However, although much effort has been devoted to studying ecological patterns in running waters across steep altitudinal gradients (see Contador et al. 2015, Moorman et al. 2006), lentic ecosystems in this region remain understudied.

The primary goals of this study, therefore, were to 1) provide a concise description of the richness and composition of freshwater macroinvertebrate communities occurring in lakes and ponds across the altitudinal gradient of a Magellanic sub-Antarctic watershed, and 2) to compare macroinvertebrate assemblage composition and functional feeding groups throughout the gradient. The results from this study complement previous descriptive studies of stream fauna, together with which they contribute to a baseline for future long-term research and monitoring of southern South American freshwater ecosystems.

\section{MATERIALS \& METHODS}

Study area

The Magellanic sub-Antarctic ecoregion, located in southern Chile, is characterized by watersheds with acute environmental clines, diverse vegetation profiles, and the presence of a wide variety of habitats and microhabitats over a short elevational range (Pisano 1977, Contador et al. 2015). This ecoregion is part of the South American forest biome, harboring the largest forest and wetland areas of the Southern Hemisphere. Embedded within the ecoregion is the Cape Horn Biosphere Reserve (CHBR; Fig 1), an area designated to protect the ecoregion from the pressures of global change (Rozzi et al. 2006). Furthermore, this region contains some of the world's cleanest rainwater, as it is located to the south of the typical tracks of industrial-polluted wind currents (Hedin, Armesto \& Johnson 1995, Weathers et al. 2000, Mach et al. 2016). Navarino Island lies in the southern part of this ecoregion. The mountain ranges in Navarino Island are characterized by short and steep altitudinal gradients (rising to $\sim 1000 \mathrm{~m}$ a.s.1.), with associated changes in air and water temperatures with elevation (Contador et al. 2015). Annual mean air temperature is $5.7^{\circ} \mathrm{C}$ close to sea level, decreasing to $0{ }^{\circ} \mathrm{C}$ at $728 \mathrm{~m}$ a.s.1. (Méndez, Rozzi \& Cavieres 2013). This study was conducted in lagoons (lakes and ponds) located along the altitudinal gradient of the Róbalo River watershed, which provides drinking water to Puerto Williams, the world's southernmost town. The annual average water temperature in the running waters of the watershed is $5.7^{\circ} \mathrm{C}$ at $120 \mathrm{~m}$ and only $1^{\circ} \mathrm{C}$ at $586 \mathrm{~m}$ a.s.l. (Contador et al. 2015).

Study site selection, habitat characterization and physico-chemical parameters

This study was conducted in lagoons located throughout the altitudinal gradient of the Róbalo river watershed (Table 1, Fig. 1). These lagoons are surrounded by evergreen forests and Sphagnum peat bogs, mixed forests and shrub patches, deciduous forests near the tree line

Peer] reviewing PDF | (2018:11:33078:1:2:NEW 9 May 2019) 
119 (Krummholz), and high Andean tundra composed of cushion plants, mosses and lichens. Four 120 lagoons were selected, located at different altitudinal levels, thus allowing for comparison 121 between the different zones found within the gradient. Along with the physical description of 122 each lagoon, the surrounding habitats were characterized. Within each lagoon, four different 123 habitat types were identified based on substrate composition, and the presence/absence and type 124 of vegetation (vascular or non-vascular): (i) rock bottoms (gravels from 1 to $10 \mathrm{~cm}$ ), (ii)

125

126

127

128

129

130

131

132

133

134

135

136

137

138

139

140

141

142

143

144

145

146

147

148

149

150

151

152

153

154

155

156

157

158 submerged vegetation (aquatic or submerged vascular plants), (iii) debris (leaf litter, roots, or logs), and (iv) aquatic mosses (completely or partially submerged). Temperature, $\mathrm{pH}$ and conductivity were measured three times in each habitat type on each sampling occasion $(n=3)$, using a multiparameter sensor (Conductivity pH TDS Hanna Tester HI98130). Additionally, HOBO ${ }^{\circledR}$ data loggers (model U22 Water Temperature Pro version 2) were permanently installed in each lagoon (anchored at $20 \mathrm{~cm}$ depth at a randomly selected location) from February 2015 until March 2016, recording water temperature every $4 \mathrm{~h}$. Mean, maximum and minimum daily and monthly temperatures $\left({ }^{\circ} \mathrm{C}\right)$ were calculated using the data obtained.

\section{Biological sampling and macroinvertebrate identification}

During the 2015 austral summer (January, February) freshwater macroinvertebrates were collected. From each lagoon three samples were taken in each habitat with a D-frame net (150 $\mu \mathrm{m}$ mesh). Each sample consisted of 1 min of net sweeping (standard sampling), and a complementary collection to obtain a comparable and representative sample of each habitat (Table 2). The latter samples were analyzed with each standard sample. Macroinvertebrates were stored in flasks in $70 \%$ ethanol, and returned to the laboratory for sorting, identification to the lowest taxonomical level possible and functional feeding group assignment according to the available literature (Domínguez \& Fernández 2009, Flint, Holzenthal \& Harris 1999, Libonatti, Michat \& Torres 2011, McLellan \& Zwick 2007, Moorman et al. 2006, Sidall \& Borda 2004, von Ellenrieder 2003). Field and sampling permits were provided by Omora Ethnobotanical Park, and field collection of specimens were approved by Universidad de Magallanes (certificate number: $\left.n^{\circ} 80 / \mathrm{CEC} / 2018\right)$.

\section{Data analyses}

Abiotic data were tested for normality and found to be non-normally distributed (Shapiro-Wilks test). The non-parametric Kruskal-Wallis (K-W) one way analysis of variance was therefore used. When significance was achieved, Wilcoxon post hoc pairwise comparisons were made. Diversity metrics were calculated for each lagoon along the altitudinal gradient. We used absolute and mean richness to describe taxonomic richness at each elevation, Shannon-Wiener diversity index $\left(\mathrm{H}^{\prime}\right)$, Peilou's evenness $\left(\mathrm{J}^{\prime}\right)$ and $\mathrm{N} 1$ of Hill's number series (Shannon-Wiener equivalent for comparison) to assess community structure (Hill 1973, Magurran 1988). Community structure indices were calculated using Primer 5.0 (Clarke 1993). Changes in macroinvertebrate assemblage richness, abundance, diversity metrics and composition were tested with the non-parametric permutation test PERMANOVA (Anderson 2001). Prior to 
159

160

161

162

163

164

165

166

167

168

169

170

171

172

173

174

175

176

177

178

179

180

181

182

183

184

185

186

187

188

189

190

191

192

193

194

195

196

197

198

PERMANOVA analyses, the PERMDISP test was performed to assess homogeneity within and between groups (Anderson 2005). Euclidean distance between pairs of observations was calculated for the univariate analyses (Claudet et al. 2006). For multivariate analyses, BrayCurtis dissimilarity matrices were calculated between pairs of observations and data were $\log (\mathrm{x}+1)$ transformed. All PERMANOVA analyses were performed using FORTRAN software (Anderson 2005). For univariate and multivariate analyses we used a factorial design, considering elevation and habitat type. To determine specific importance of macroinvertebrates at each site, and their associated functional feeding group, we used the Similarity Percentages multivariate analysis SIMPER (Primer 5.0, Clarke 1993), with a 90\% contribution cutoff.

\section{RESULTS}

Altitudinal abiotic parameters

The sampled lagoons remained surface frozen for between four and seven months, with water temperature dropping to around $0{ }^{\circ} \mathrm{C}$ in the first weeks of May (austral autumn) and subsequently, depending on elevation, beginning to thaw in mid-September (austral spring) to mid-December (austral summer). The maximum average temperature was recorded in Castor lagoon (20 m a.s.1.), reaching $16.99^{\circ} \mathrm{C}$ in December, while the minimum average temperature recorded was $-0.19^{\circ} \mathrm{C}$ in June in Róbalo lake (Fig. 2).

Conductivity showed significant differences along the altitudinal gradient (K-W, $\mathrm{P}<0.0001$, Supplementary Table 1) associated with the increase of elevation, ranging from 147.3 to $49.5 \mu \mathrm{S}$ (Table 3). Significant differences in $\mathrm{pH}$ were detected between Castor lagoon and the remaining three sampled lagoons along the gradient $(\mathrm{K}-\mathrm{W}, \mathrm{P}<0.0001)$. This low elevation lagoon showed acidic values, while the others were close to neutral $\mathrm{pH}$. Water temperature recorded in the sampling events showed significant variation between elevations (K-W, $\mathrm{P}<0.0001$, Supplementary Table 1), decreasing with increasing altitude.

\section{Altitudinal diversity metrics}

Taxonomic richness

A total of 9384 macroinvertebrates were collected in the study, from which we identified 28 taxa belonging to 13 orders and 17 families. Of the 28 taxa, 16 were identified to genus/species level, and the remaining to order, family or subfamily level, catalogued as morpho-species

(Supplementary Table 2). Sites at lower elevations showed the highest absolute richness, $\mathrm{S}=18$ at $20 \mathrm{~m}$ and $\mathrm{S}=17$ at $250 \mathrm{~m}$ a.s.l., while in sites at the higher elevations we recorded fewer taxa, $\mathrm{S}=11$ at $480 \mathrm{~m}$ and $\mathrm{S}=6$ at $700 \mathrm{~m}$ a.s.1.

Altitudinal variation in richness, abundance and diversity metrics

The permutation analysis detected significant differences in mean macroinvertebrate richness between elevations and habitats (PERMANOVA, Elev F = 39.695, $\mathrm{P}=0.0002$; Hab F = 5.2073, $\mathrm{P}=0.0056$, Fig. 3, Supplementary Table 3). Castor lagoon, at $20 \mathrm{~m}$ a.s.l., had a significantly 
199 higher mean richness than the other elevations. Pairwise comparisons detected differences 200 between all elevations, with the exception of 250 and $480 \mathrm{~m}$ a.s.l. (pairwise comparison, $\mathrm{P}=$ 201 0.5779, Supplementary Table 4). Significant differences were also detected in macroinvertebrate 202 mean abundance along the elevation gradient (Fig. 3), between the habitats and in interactions 203 between factors (PERMANOVA, Elev $\mathrm{F}=56.544, \mathrm{P}=0.0002$; Hab F $=12.54, \mathrm{P}=0.0002$; Elev $204 \times \mathrm{Hab} F=10.515, \mathrm{P}=0.0002$, Supplementary Table 3 ). Mean abundance was significantly 205 different between all elevations, between rock bottom habitats and the other three habitat types 206 (pairwise comparisons in Supplementary Table 4). Differences in diversity $\left(\mathrm{H}^{\prime}, \mathrm{N} 1\right)$ and 207

208 209 decreasing as elevation increased (PERMANOVA, Shannon index, $\mathrm{F}=31.566, \mathrm{P}=0.0002$; Hill's N1 F $=25.478, \mathrm{P}=0.0002$, Pielou's evenness F $=18.156, \mathrm{P}=0.0002$, Supplementary Table 3), and indicating a more uniform community at $700 \mathrm{~m}$ a.s.l. in Bandera lagoon. However, significant differences in mean abundance between habitats were found for the Shannon diversity index and Pielou's evenness (PERMANOVA, Shannon index F = 3.4004, $\mathrm{P}=0.0294$; Pielou's evenness $\mathrm{F}=5.9582, \mathrm{P}=0.0026$; pairwise comparisons in Supplementary Table 4).

Altitudinal community structure

The freshwater macroinvertebrate assemblage showed variability along the gradient, although there were common elements through different elevations. In Bandera lagoon, $700 \mathrm{~m}$ a.s.l., $78.22 \%$ of the assemblage was represented by the freshwater amphipod genus Hyalella, with oligochaetes contributing 14.8\% (Table 4, Fig. 4). In a similar fashion, in El Salto lagoon, Hyalella amphipods and oligochaetes were the most frequent taxa $(49.67 \%$ and $24.68 \%$, respectively; Table 4, Fig. 4). In Róbalo lake, $250 \mathrm{~m}$ a.s.l., amphipods represented almost half of the community (46.72\%), while oligochaetes, leptophlebiid mayflies, biting and non-biting midges, leeches, and lymnaeid snails comprised the remaining representative fauna (Table 4, Fig. 4). The abundant Hyalella amphipods (30.59\%), non-biting midges, lechees, diving beetles and water boatmen were the most abundant taxa in Castor lagoon, $20 \mathrm{~m}$ a.s.l. (Table 4, Fig. 4). Significant differences in macroinvertebrate community composition were apparent along the elevation gradient, between the habitats and in interactions between factors (PERMANOVA, Elev $\mathrm{F}=39.695, \mathrm{P}=0.0002$; Hab $\mathrm{F}=5.2073, \mathrm{P}=0.0002$; Elev $\times \mathrm{Hab} \mathrm{F}=1.4874, \mathrm{P}=0.0002$, Supplementary Table 5). Pairwise comparisons detected differences between all elevations and habitats, with the exception between submerged vegetation and two other habitats (pairwise comparison, rock bottoms $\mathrm{P}=0.1376$, aquatic mosses $\mathrm{P}=0.0852$, Supplementary Table 6 ).

Functional feeding groups (FFG) comprised six main categories: collector-filterers, collectorgatherers, collector-predators, herbivores (grazers, shredders and/or piercers), predators, and scrapers. Collector-gatherers and predators where present in every lagoon, although with varying representativeness. Collector-gatherers were the dominant group at all elevations, with representativeness increasing with elevation, ranging from $48.7 \%$ at $20 \mathrm{~m}$ a.s. 1 . to $99.7 \%$ at 700 m a.s.l. (Table 5, Fig. 5). Predators comprised almost a quarter of the FFG assemblage at each 
239 elevation, excepting a marked decrease at $700 \mathrm{~m}$ a.s.l. (to $0.3 \%$ ). Herbivores, collector-filterers, 240 collector-predators and scrapers were present at almost every elevation, but rarely represented 241 more than $10 \%$ of the total assemblage (Table 5, Fig. 5). Similar to community composition, 242 significant differences were found in FFG composition with elevation, between habitats and in 243 their interaction (PERMANOVA, Elev $\mathrm{F}=25.168, \mathrm{P}=0.0002$; Hab F $=4.6319, \mathrm{P}=0.0002$;

244 Elev x Hab F = 2.1298, P = 0.0002, Supplementary Table 7). Differences between all elevations 245 and habitats were detected by pairwise comparisons, excepting between submerged vegetation 246 and two other habitats (pairwise comparison, rock bottoms $\mathrm{P}=0.0544$, aquatic mosses $\mathrm{P}=$ 247 0.3382, Supplementary Table 8).

248

\section{DISCUSSION}

250

251

252

253

254

255

256

257

258

259

260

261

262

263

264

265

266

267

268

269

270

271

272

273

274

275

276

277

278
The variation of water temperature across spatio-temporal gradients is one of the key abiotic drivers that shape the distribution, ecology and biology of freshwater macroinvertebrates (Vannote et al. 1980). Latitudinal and altitudinal gradients are recognized as ecological analogues and drivers of environmental gradients, with both being considered proxies of temperature variation (Dos Santos et al. 2018). As expected, water temperature showed a marked decrease associated with increasing elevation, while snow and ice cover had longer duration at higher elevations. Similar to altitudinal studies in streams of the Róbalo river watershed (Contador et al. 2015), the lagoon water temperatures reported here dropped markedly over a short geographical distance. This short and steep gradient, and associated environmental clines, stand out when compared to similar magnitude changes in, for example, the Andean region (Jacobsen 2004, Scheibler, Claps \& Roig-Juñent 2014), Patagonian streams (Miserendino \& Pizzolón 2000, 2003), or in the Northern Hemisphere Rocky Mountains (Hauer et al. 1997). Several studies have focused on temperature and elevation gradient effects on freshwater macroinvertebrates in South America (Nieto et al. 2016, Shah et al. 2017, Dos Santos et al. 2018). Nevertheless, austral and remote regions, such as Tierra del Fuego and the Cape Horn Biosphere Reserve, have received little attention in this regard (Contador, Kennedy \& Rozzi 2012).

In terms of abiotic features other than temperature, lagoons in the CHBR have a circum-neutral $\mathrm{pH}$, with the exception of the low elevation Castor lagoon ( $20 \mathrm{~m}$ a.s.l.), whose acidic $\mathrm{pH}$ is likely caused by the adjacent peat bog complex. Conductivity shows a similar trend, with low values in the higher altitude lagoons and higher values at low elevations, again likely to be related to the surrounding peat bog and associated organic matter input. Moorman et al. (2006) noted that low conductivity values indicate a lack of pollution in these CHBR freshwater systems, and Mach et al. (2016) reported very low to undetectable levels of inorganic pollutants.

Macroinvertebrate groups recorded in this study with the highest species richness were Diptera and Trichoptera, especially chironomid midges and limnephilid caddisflies, while Hyalella amphipods were the most abundant taxon throughout the gradient. Similar composition patterns 
279 have previously been described in Patagonian and Magellanic sub-Antarctic streams

280 (Miserendino \& Pizzolón 2000, Contador et al. 2015), and also in the Argentinean Andes

281 (Scheibler, Claps \& Roig-Juñent 2014). Palma (2013), divides Chile into four macroclimatic

282 zones, the arid north, the Mediterranean center, the temperate south, and Patagonia, which may

283 underlie mayfly, stonefly and caddisfly distribution patterns. Nonetheless, in the Patagonian

284 ecoregion two contrasting climatic zones can be identified, an arid steppe region east of the

285 Andes mountain range and hyperhumid forests and wetlands south-west of this mountain range.

286 The latter is known as the Magellanic sub-Antarctic ecoregion (Rozzi et al. 2006). Besides

287 having an understudied freshwater biodiversity, climatic conditions in this ecoregion support a

288 highly endemic but relatively low diversity macroinvertebrate fauna and, at the same time, the

289

290

291

292

293

294 region includes the southern latitudinal limit for several insect orders.

295

296

297

298

299

300

301

302

303

304

305

306

307

308

309

310

311

312

313

314

315

316

317

318

Our results show a low-plateau then monotonic decline in richness with increasing elevation, which indicates that community composition is simpler and, in this case, more even (Pielou's index) towards higher altitude. This pattern differs from the mid-peak trend found in streams of the same watershed (Contador et al. 2015). Similar tendencies have also been reported in Andean, and central and southern Argentinian streams (Corigliano et al. 1996, Miserendino \& Pizzolón 2000, 2003, Scheibler, Claps \& Roig-Juñent 2014). Elevation-restricted taxa associated with the studied lagoons may have particular potential in research addressing the biotic responses to global and regional climate change. For example, in our study daphniid cladocerans, small hydroporine dytiscids, corixids and the southernmost distributed dragonfly, Rhionaeschna variegata, were restricted to the low elevation sampled lagoons, and are also not present in streams of the same watershed (Contador et al. 2015). Whilst widespread in the stream elevation gradient (Contador et al. 2015, Contador \& Kennedy 2016), limnephilid caddisflies and leptophlebiid mayflies were restricted to mid elevations, where they were common in lagoon assemblages.

This study confirms that elevation has strong effects on community structure, function and environmental features, even in a relatively low elevation mountain range. The harsh environmental conditions of the Magellanic sub-Antarctic ecoregion, which include long periods of ice and snow cover, as well as chronically low temperatures, reduces the opportunity for development thereby increasing development time, as well as habitat availability and food supply, supporting simple but well adapted communities.

The data obtained provide a descriptive baseline of ecological features of macroinvertebrate communities associated with lentic freshwater ecosystems in sub-Antarctic Chile. In conjunction with previous stream studies, it provides a watershed-scale platform of information that is a necessary underpinning for future long-term research in the region. The Magellanic subAntarctic ecoregion stands out as an ideal natural laboratory in which to explore how biota will respond to different global environmental change scenarios.

Peer) reviewing PDF | (2018:11:33078:1:2:NEW 9 May 2019) 


\section{CONCLUSIONS}

321

322

323

324

325

326

327

328

329

330

331

332

333

334

335

336

337

338

339

340

341

342

343

344

345

346

347

348

349

350

351

352

353

354

355

356

357

The short $(1000 \mathrm{~m})$ and accessible altitudinal gradient, associated with strong decreases in air and water temperatures, makes the Magellanic sub-Antarctic region an ideal natural laboratory to understand ecological responses to environmental gradients and changes. This study confirms that freshwater macroinvertebrate diversity and community features in this region are strongly influenced by temperature gradients.

\section{ACKNOWLEDGEMENTS}

The authors thank the Sub-Antarctic Biocultural Conservation Program for logistics and support in Navarino Island, Chile. This work is a contribution of the Wankara Sub-Antarctic and Antarctic Freshwater Ecosystems Laboratory, Universidad de Magallanes, Puerto Williams, Chile.

\section{REFERENCES}

Anderson M. J. (2001). A new method for non-parametric multivariate analysis of variance. Austral Ecology, 26: 32-46.

Anderson M. J. (2005). PERMANOVA: a FORTRAN computer program for permutational multivariate analysis of variance. Department of Statistics, University of Auckland, New Zealand, 24.

Balian E. V., Segers H., Lévêque C. \& Martens K. (2008). The freshwater animal diversity assessment: an overview of the results. Hydrobiologia, 595: 627-637.

Boggs C. L. (2016). The fingerprints of global climate change on insect populations. Current Opinion in Insect Science, 17: 69-73.

Bozinovic F., Calosi P. \& Spicer J. I. (2011). Physiological correlates of geographic range in animals. Annual Review of Ecology, Evolution, and Systematics, 42: 155-179.

Čiamporová-Zat'ovičová Z., Hamerlík L., Šporka F. \& Bitušík P. (2010). Littoral benthic macroinvertebrates of alpine lakes (Tatra Mts) along an altitudinal gradient: a basis for climate change assessment. Hydrobiologia, 648(1): 19-34.

Clarke K. R. (1993). Non-parametric multivariate analysis of changes in community structure. Australian Journal of Ecology, 18: 117-143.

Claudet J., Pelletier D., Jouvenel J. Y., Bachet, F. \& Galzin R. (2006). Assessing the effect of marine protected area (MPA) on a reef fish assemblage in a Northwestern Mediterranean Marine reserve: identifying community-based indicators. Biological Conservation, 130: 349-369. Contador T., Kennedy J. H. \& Rozzi R. (2012). The conservation status of South American aquatic insects in the literature. Biodiversity Conservation, 21: 2095-2107. Contador T. \& Kennedy J. (2016). The life histories of Meridialaris chiloeensis (Demoulin, 1955) (Ephemeroptera: Leptophlebiidae) and Gigantodax rufescens (Edwards, 1931) (Diptera:

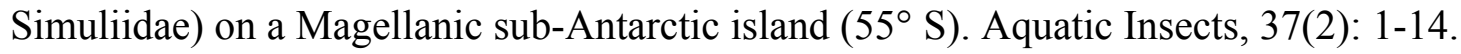


358 Contador T., Kennedy J.H, Ojeda J., Feinsiner P. \& Rozzi R. (2014). Ciclos de vida de insectos

359

360

361

362

363

364

365

366

367

368

369

370

371

372

373

374

375

376

377

378

379

380

381

382

383

384

385

386

387

388

389

390

391

392

393

394

395

396

dulceacuícolas y cambio climático global en la ecorregión subantártica de Magallanes: investigaciones ecológicas a largo plazo en el Parque Etnobotánico Omora, Reserva de Biosfera Cabo de Hornos (55 ${ }^{\circ}$ S). Revista Bosque, 35(3), 429: 437.

Contador T., Kennedy J. H., Rozzi R. \& Ojeda J. (2015). Sharp altitudinal gradients in Magellanic Sub-Antarctic streams: patterns along a fluvial system in the Cape Horn Biosphere Reserve (55 S). Polar Biology, 38(11): 1853-1866.

Corigliano M. C., Gualdoni C. M., Oberto A. M. \& Raffaini G. B. (1996). Macroinvertebrados acuáticos de Córdoba. Biodiversidad de la Provincia de Córdoba. Fauna, 1: 119-165.

de Mendoza G. \& Catalán J. (2010). Lake macroinvertebrates and the altitudinal environmental gradient in the Pyrenees. Hydrobiologia, 648(1): 51-72.

Domínguez E. \& Fernández H. R. (2009). Macroinvertebrados bentónicos sudamericanos.

Sistemática y Biología. Fundación Miguel Lillo, Tucumán, Argentina.

Dos Santos D. A., Molineri C., Nieto C., Zúñiga M. C., Emmerich D., Fierro P., Pessaq P., Rios-

Touma B., Márquez J., Gómez D., Salles F. F., Encalada A. C., Príncipe R., Gómez G. C.,

Valdovinos Zarges C. \& Domínguez E. (2018). Cold/Warm stenothermic freshwater

macroinvertebrates along altitudinal and latitudinal gradients in Western South America: A modern approach to an old hypothesis with updated data. Journal of Biogeography. 00:1-11. Flint O. S., Holzenthal R. W. \& Harris S. C. (1999). Nomenclatural and Systematic changes in the Neotropical caddisflies (Insecta: Trichoptera). Insecta Mundi, 13: 73-84.

Glasser N. F., Jansson K. N., Harrison S. \& Klenan J. (2008). The glacial geomorphology and Pleistocene history of South America between $38^{\circ} \mathrm{S}$ and $56^{\circ} \mathrm{S}$. Quaternary Science Reviews, 27: 365-390.

Hauer R. F., Baron J. S., Campbell D. H., Fausch K. D., Hostetler W., Leavesley G. H., Leavitt P. R., McKnight D. M. \& Stanford J.A. (1997). Assessment of climate change and freshwater ecosystems of the Rocky Mountains, USA and Canada. Hydrological Process 11: 903-924.

Hedin L. O., Armesto J. J. \& Johnson A. H. (1995). Patterns of nutrient loss from unpolluted, old-growth temperate forests: Evaluation of biogeochemical theory. Ecology, 76(2), 493-509. Hill M. O. (1973). Diversity and eveness: a unifying notation and its consequences. Ecology, 54: 427-432.

Hulton N. R. J., Purves R.S., McCulloch R. D., Sugden D. E. \& Bently M. J. (2002). The last glacial maximum in southern South America. Quaternary Science Reviews, 21:233-241 Jacobsen D. (2004). Contrasting patterns in local and zonal family richness of stream invertebrates along Andean altitudinal gradient. Freshwater Biology, 49: 1293-1305. Kremen C., Colwell R. K., Erwin T. L., Murphy D. D., Noss R. F. \& Sanjayan M. A. (1993). Terrestrial arthropod assemblages: their use in conservation planning. Conservation Biology, 7 : 796-808.

Libonatti M. L., Michat M. C., Torres P. (2011). Claves para los adultos de las subfamilias, tribus y géneros de Dytiscidae de la Argentina (Coleoptera: Adephaga). 70(3-4): 317-336.

Peer) reviewing PDF | (2018:11:33078:1:2:NEW 9 May 2019) 
397 Lomolino M. (2001). Elevation gradients of species-density: historical and prospective views.

398 Global Ecology and Biogeography, 10(1): 3-13.

399 Mach P. M., Winfield J. L., Aguilar R. A., Wright K. C. \& Verbeck G. F. (2016). A portable

400 mass spectrometer study targeting anthropogenic contaminants in Sub-Antarctic Puerto

401 Williams, Chile. International Journal of Mass Spectrometry.

402 McLellan I. D. \& Swick P. (2007). New species and keys to South American Gripopterygidae 403 (Plecoptera). Illiesia, 3(4): 20-42.

404 Magurran A. E. (1988). Ecological diversity and its measurement. Princeton University Press, 405 New Jersey, 179 pp.

406 McCain, C. M. \& Grytnes, J. A. (2010). Elevational gradients in species richness. Encyclopedia 407 of life sciences (ELS), 1-10.

408 Méndez M., Rozzi R. \& Cavieres L. (2013). Flora vascular y no-vascular en la zona altoandina 409 de la isla Navarino ( $55^{\circ} \mathrm{S}$ ), Reserva de Biosfera Cabo de Hornos, Chile. Gayana Botánica, 70(2): 410 337-343.

411 Millennium Ecosystem Assessment (MEA) (2005). Ecosystems and human well-being:

412 Wetlands and water synthesis. Washington, DC: World Resources Institute.

413 Miserendino M. L. (2009). Effects of flow regulation, basin characteristics and land-use on 414 macroinvertebrate communities in a large arid Patagonian River. Biodiversity and Conservation, 415 18: 1921-1943.

416 Miserendino M. L. \& Pizzolón L. A. (2000). Macroinvertebrates of a fluvial system in

417 Patagonia: altitudinal zonation and functional structure. Archiv Fur Hydrobiologie, 150: 55-83

418 Miserendino M. L. \& Pizzolón L. A. (2003). Distribution of macroinvertebrate assemblages in 419 the Azul-Quemquemtreu River Basin, Patagonia, Argentina. New Zealand Journal of Marine 420 And Freshwater Research, 37: 525-539.

421 Mittermeier, R.A., Mittermeier, C. G., Brooks, T. M, Pilgrim, J. D., Konstant, W. R., Fonseca 422 G.A. \& Kormos, C. (2003). Wilderness and biodiversity conservation. Proceedings of the 423 National Academy of Sciences, 100:10309-10313.

424 Moorman M. C., Anderson C. B., Gutiérrez A. G., Charlin R. \& Rozzi R. (2006). Watershed 425 conservation and aquatic benthic macroinvertebrate diversity in the Alberto D'Agostini National 426 Park, Tierra del Fuego, Chile. Anales del Instituto de la Patagonia, 34: 41-58

427 Nieto C., Malizia A., Carilla J., Izquierdo A., Rodríguez J., Cuello S., Zannier M. \& Grau, H. R. 428 (2016). Patrones espaciales en comunidades de macroinvertebrados acuáticos de la Puna 429 Argentina. Revista de Biología Tropical, 64(2): 747-762.

430 Palma A. (2013). Importancia de las regiones mediterránea, templada y patagónica en la 431 diversidad de Ephemeroptera, Plecoptera y Trichoptera: implicancias de futuros cambios 432 ambientales en sus distribuciones. Boletín de Biodiversidad de Chile, (8), 37-47.

433 Pisano E. (1977). Fitogeografía de Fuego-Patagonia Chilena 1. Comunidades vegetales entre las 434 latitudes 52-56 S. Anales del Instituto de la Patagonia, 8: 121-250.

435 Rahbek C. (1995). The elevational gradient of species richness: a uniform pattern?. Ecography, 436 18(2): 200-205. 
437 Rozzi R., Armesto J. J., Gutiérrez J., Massardo F., Likens G., Anderson C. B., Poole A., Moses 438 K., Hargrove G., Mansilla A., Kennedy J. H., Wilsson M., Jax K., Jones C., Callicott J. B. \& 439 Kalin M. T. (2012). Integrating ecology and environmental ethics: Earth stewardship in the 440 southern end of the Americas. BioScience, 62(3): 226-236.

441 Rozzi R., Massardo F., Anderson C. B., Heidinger K. \& Silander Jr. J. A. (2006). Ten principles 442 for biocultural conservation at the southern tip of the Americas: the approach of the Omora 443 Ethnobotanical Park. Ecology and Society, 11(1).

444 Scheibler E. E., Claps M. C. \& Roig-Juñent S. A. (2014). Temporal and altitudinal variations in 445 benthic macroinvertebrate assemblages in an Andean river basin of Argentina. Journal of 446 Limnology, 73(1): 92-108.

447 Shah A.,Gill B., Encalada A.,Flecker A., Chris Funk W., Guayasamin J., Kondratieff B., LeRoy 448 Poff W., Thomas S., Zamudio K. \& Ghalambor C. (2017). Climate variavility predicts thermal 449 limits of aquatic insects across elevation and latitude. Functional Ecology, 31(11): 2118-2127. 450 Siddall M. E. \& Borda E. (2004). Leech collections from Chile including two new species of 451 Helobdella (Annelida: Hirudinida). American Museum Novitates, 1-18.

452 Vannote R. L., Minshall G. W., Cummins K. W., Sedell J. R. \& Cushing C. E. (1980). The river 453 continuum concept. Canadian journal of fisheries and aquatic sciences, 37(1): 130-137.

454 von Ellenrieder N. (2003). A synopsis of the Neotropical species of "Aeshna" Fabricius: the 455 genus Rhionaeschna Förster (Odonata: Aeshnidae). Tijdchrift voor Entomologie, 146: 67-207. 456 Vörösmarty C. J., McIntyre P. B., Gessner M. O., Dudgeon D., Prusevich A., Green P., Glidden 457 S., Bunn S. E., Sullivan C. A., Reidy Liermann C. \& Davies P. M. (2010). Global threats to 458 human water security and river biodiversity. Nature, 467: 555-561.

459 Weathers K. C., Lovett G. M., Likens G. \& Caraco N. F. M. (2000). Cloudwater inputs of 460 nitrogen to forest ecosystems in southern Chile: Forms, fluxes, and sources. Ecosystems, 3: 590461595. 
Figure 1

Cape Horn Biosphere Reserve and study sites on Navarino Island

Location of the Cape Horn Biosphere Reserve in Southern South America. Navarino Island and study sites from the Róbalo river watershed are zoomed. $\mathrm{CL}=$ Castor lagoon, $\mathrm{RL}=$ Róbalo lake, $\mathrm{SL}=$ el Salto lagoon, $\mathrm{BL}=$ Bandera lagoon.

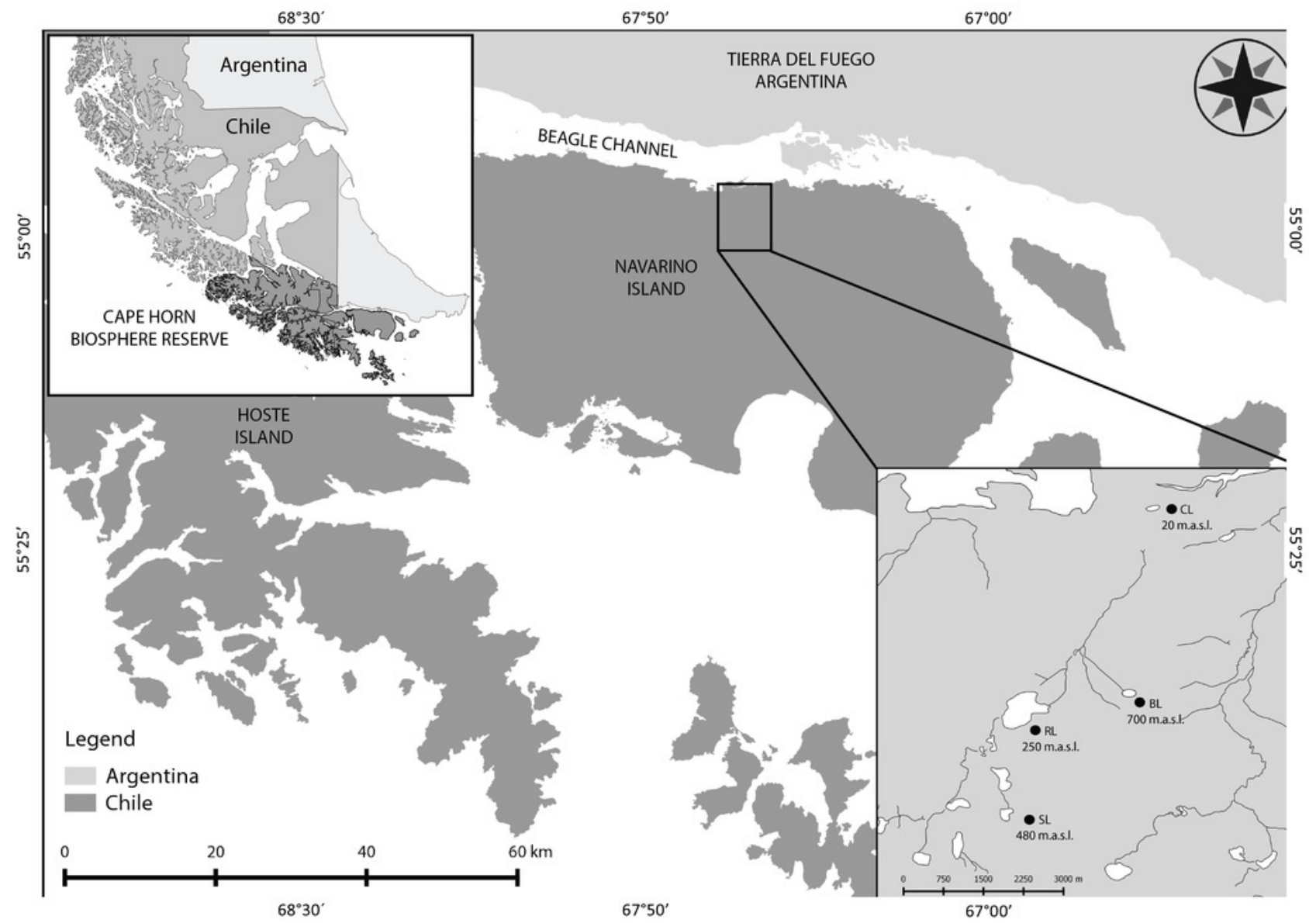


Figure 2 (on next page)

Water temperature profiles.

Lagoon monthly water temperature profiles retrieved from data loggers. Different color lines indicate a different lagoon. 
Figure 3 (on next page)

Richness and abundance of sub-Antarctic freshwater macroinvertebrates.

Mean richness and mean abundance $( \pm \mathrm{SE})$ of freshwater macroinvertebrates associated to the four studied lagoons from the Róbalo river watershed, Navarino Island, Southern Chile, during 2015. Bold a, b, c and d indicate significant differences in mean richnnes, italic a and $b$ indicate significant differences in mean abundance $(p<0.05)$. 
Figure 4

Sub-Antarctic freshwater macroinvertebrate community composition.

SIMPER contribution percentages of sub-Antarctic freshwater macroinvertebrates associated to lagoons from the Róbalo river watershed on Navarino Island during 2015. Elevation of each lagoon is indicated in pie chart. Abreviations, Chiro $=$ Chironomidae, Daph $=$ Daphnidae, Glos= Glosiphoniidae, Oligo $=$ Oligochaeta, Orth= Orthocladiinae, Tany $=$ Tanypodinae, morph = morphotype.

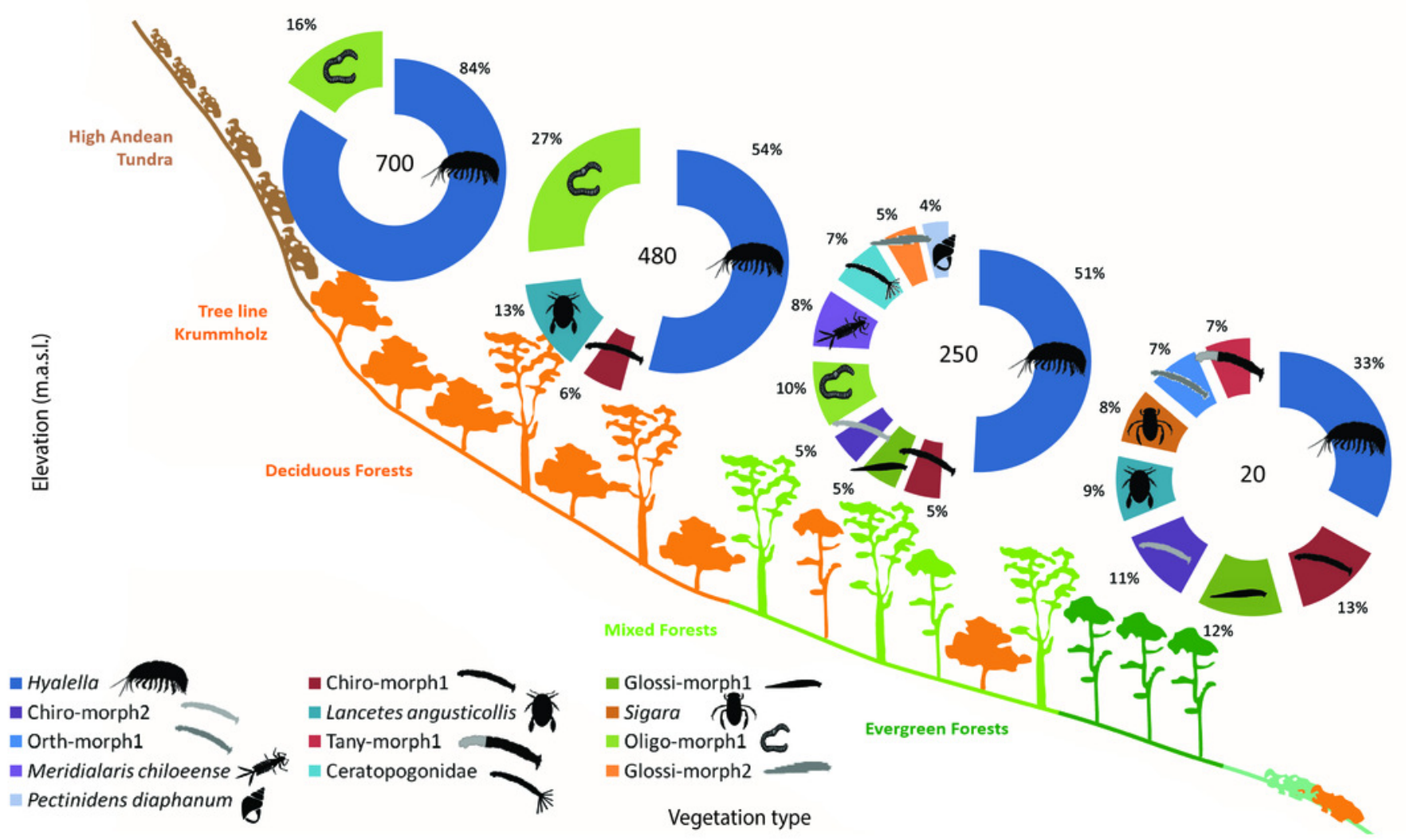




\section{Figure 5}

Sub-antarctic freshwater macroinvertebrates functional feeding groups.

SIMPER contribution percentages of sub-Antarctic freshwater macroinvertebrate functional feeding groups associated to lagoons from the Róbalo river watershed on Navarino Island during 2015. Elevation of each lagoon is indicated in pie chart.

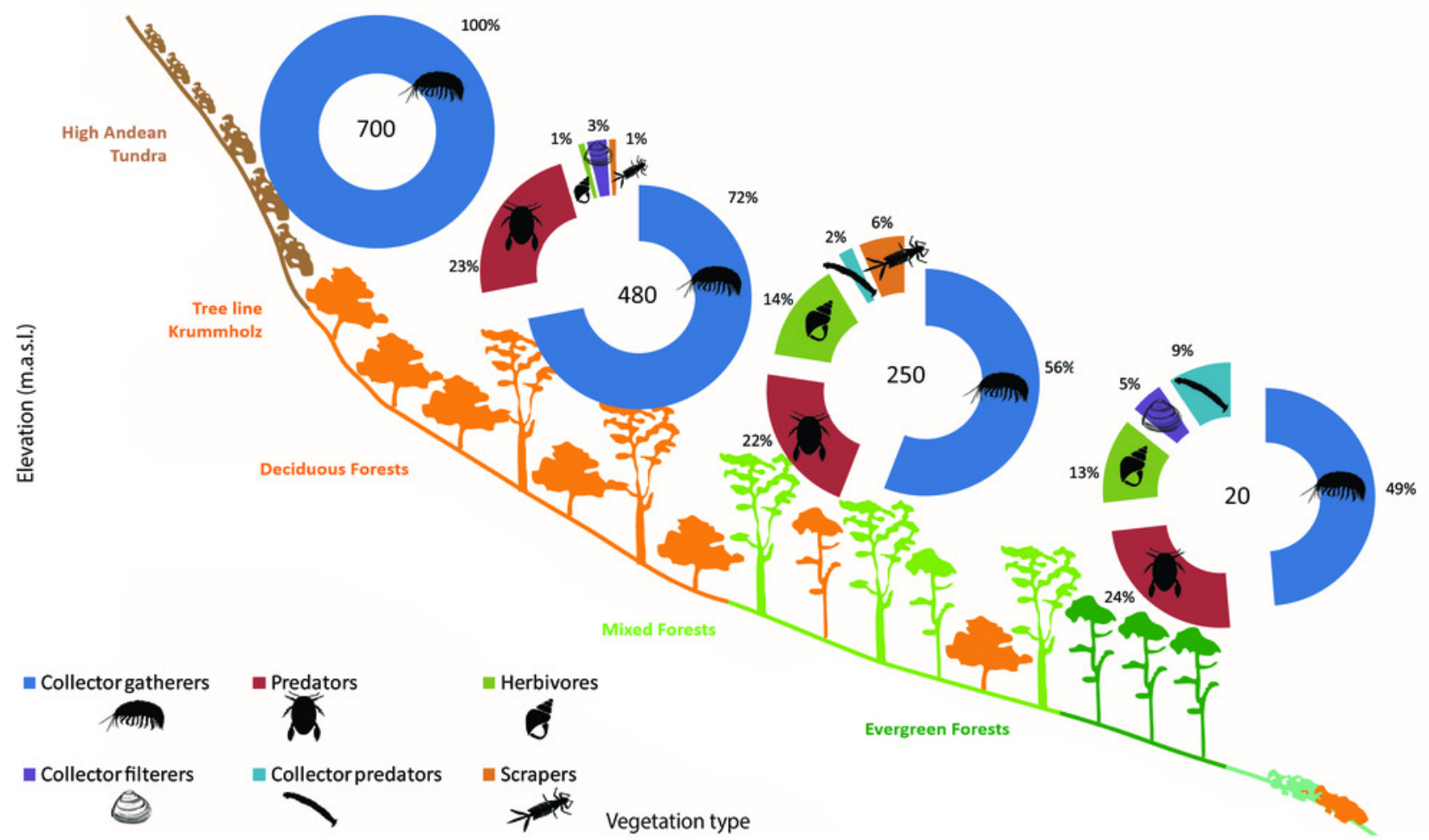




\section{Table 1 (on next page)}

Study sites

Physical description of the four sampled lagoons along the elevation gradient of the Róbalo river watersed, Navarino Island, Chile. 


\begin{tabular}{|c|c|c|c|c|c|}
\hline Site & Name & Georeference & $\begin{array}{l}\text { Elevation } \\
\text { (m.a.s.l) }\end{array}$ & $\begin{array}{c}\text { Water inflow and/ } \\
\text { or outflow }\end{array}$ & Adjacent vegetation \\
\hline I & $\begin{array}{l}\text { Castor } \\
\text { lagoon }\end{array}$ & $\begin{array}{l}54^{\circ} 56^{\prime} 19^{\prime \prime} \mathrm{S} / \\
67^{\circ} 38^{\prime} 15^{\prime \prime} \mathrm{W}\end{array}$ & 20 & Diffuse & $\begin{array}{l}\text { Evergreen forests and } \\
\text { Sphagnum peatlands }\end{array}$ \\
\hline II & $\begin{array}{l}\text { Róbalo } \\
\text { lake }\end{array}$ & $\begin{array}{l}54^{\circ} 58^{\prime} 12^{\prime \prime} \mathrm{S} / \\
67^{\circ} 40^{\prime} 29^{\prime \prime} \mathrm{W}\end{array}$ & 250 & $\begin{array}{l}\text { South located inflow, } \\
\text { outflow at North-East }\end{array}$ & $\begin{array}{l}\text { Mixed deciduous and } \\
\text { evergreen forests and } \\
\text { scrublands }\end{array}$ \\
\hline III & $\begin{array}{l}\text { E1 Salto } \\
\text { lagoon }\end{array}$ & $\begin{array}{l}54^{\circ} 59^{\prime} 26^{\prime \prime} \mathrm{S} / \\
67^{\circ} 40^{\prime} 56^{\prime \prime} \mathrm{W}\end{array}$ & 480 & $\begin{array}{c}\text { South located inflow, } \\
\text { outflow at North }\end{array}$ & $\begin{array}{c}\text { Scrub forests, mosses and } \\
\text { herbs }\end{array}$ \\
\hline IV & $\begin{array}{l}\text { Bandera } \\
\text { lagoon }\end{array}$ & $\begin{array}{l}54^{\circ} 58^{\prime} 26^{\prime \prime} \mathrm{S} / \\
67^{\circ} 38^{\prime} 41^{\prime \prime} \mathrm{W}\end{array}$ & 700 & $\begin{array}{c}\text { South-East located } \\
\text { inflow, outflow at } \\
\text { West }\end{array}$ & $\begin{array}{l}\text { Mosses, lichens and } \\
\text { cushion plants }\end{array}$ \\
\hline
\end{tabular}

1 


\section{Table 2 (on next page)}

Sampling methods.

Standard and complementary sampling for each microhabitat in each lagoon at Róbalo river watershed, Navarino Island, Chile. Sampling time unit corresponds to one minute. 


\begin{tabular}{ccc}
\hline Habitat type & Standard sampling & Complementary sampling \\
\hline Rock bottoms & D-frame net per time unit & Rinse and dislodge organisms from rocks \\
\hline $\begin{array}{c}\text { Submerged } \\
\text { vegetation }\end{array}$ & D-frame net per time unit & $25 \mathrm{~cm}^{2}$ to $64 \mathrm{~cm}^{2}$ plant collection (according \\
microhabitat availability)
\end{tabular}

1 


\section{Table 3(on next page)}

Abiotic parameters.

Mean values and non parametric Kruskal-Wallis analysis of variance and for abiotic parameters measured at sampling sites in the Róbalo river watershed, Navarino Island, Chile. Values with asterisks represent significant differences $(p<0.05)$. 


\begin{tabular}{ccccccc}
\hline & \multicolumn{9}{c}{ Elevation (m.a.s.l.) and mean values $( \pm$ SE) } & & \\
\cline { 2 - 5 } Parameter & $\mathbf{2 0}$ & $\mathbf{2 5 0}$ & $\mathbf{4 8 0}$ & $\mathbf{7 0 0}$ & H & $\boldsymbol{p}$ \\
\hline $\begin{array}{c}\text { Conductivity } \\
(\mu \mathrm{S} / \mathrm{cm})\end{array}$ & $147.3(1.23)$ & $67.25(3.89)$ & $57.08(2.31)$ & $49.5(6.84)$ & 41.267 & $<0.0001^{*}$ \\
$\mathrm{pH}$ & $5.97(0.09)$ & $7.67(0.1)$ & $7.83(0.22)$ & $7.61(0.21)$ & 30.8702 & $<0.0001^{*}$ \\
Temperature $\left({ }^{\circ} \mathrm{C}\right)$ & $11.03(0.11)$ & $9.71(0.09)$ & $6.46(0.19)$ & $5.37(0.17)$ & 44.4119 & $<0.0001^{*}$ \\
\hline
\end{tabular}




\section{Table 4 (on next page)}

Sub-Antarctic freshwater macroinvertebrate community composition.

Similarity Percentages (SIMPER) analysis of freshwater macroinvertebrate community composition that contribute approximately $90 \%$ of the abundance of the assemblage from sampling sites of the Róbalo river watershed, Navarino Island, Chile. Abreviations, Av. Abund. Average Abundance, $\operatorname{Sim} / \mathrm{SD}=$ Similarity Standard Deviation, Contrib. $=$ Contribution, Cum. $=$ Cumulative, Chiro $=$ Chironomidae, $\mathrm{Daph}=$ Daphnidae, Glos $=$ Glosiphoniidae, Oligo= Oligochaeta, Orth $=$ Orthocladiinae, Tany $=$ Tanypodinae, morph = morphotype . 


\begin{tabular}{|c|c|c|c|c|c|}
\hline $\begin{array}{l}\text { Elevation } \\
\text { (m.a.s.l.) }\end{array}$ & Species & Av. Abund. & $\operatorname{Sim} / \mathbf{S D}$ & Contrib. \% & Cum. \% \\
\hline \multirow{8}{*}{20} & Hyalella sp. & 5.42 & 5.78 & 30.59 & 30.59 \\
\hline & Chiro-morph1 & 2.66 & 1.1 & 11.64 & 42.22 \\
\hline & Glossi-morph1 & 2.1 & 2.52 & 11.35 & 53.57 \\
\hline & Chiro-morph2 & 2.16 & 1.13 & 10.05 & 63.62 \\
\hline & Lancetes angusticollis & 1.91 & 2.6 & 8.76 & 72.39 \\
\hline & Sigara sp. & 2.06 & 1.57 & 7.31 & 79.69 \\
\hline & Orth-morph 1 & 2.21 & 1.01 & 6.68 & 86.38 \\
\hline & Tany-morph1 & 1.92 & 1.2 & 6.01 & 92.39 \\
\hline \multirow{9}{*}{250} & Hyalella sp. & 2.73 & 3.53 & 46.72 & 46.72 \\
\hline & Oligo-morph1 & 0.88 & 0.9 & 8.82 & 55.54 \\
\hline & Meridialaris chiloeense & 0.8 & 0.59 & 7.62 & 63.16 \\
\hline & Ceratopog-morph1 & 0.47 & 0.55 & 6.76 & 69.92 \\
\hline & Glossi-morph1 & 0.42 & 0.65 & 4.99 & 74.91 \\
\hline & Chiro-morph1 & 0.66 & 0.47 & 4.83 & 79.75 \\
\hline & Glossi-morph2 & 0.86 & 0.41 & 4.38 & 84.12 \\
\hline & Chiro-morph2 & 0.61 & 0.65 & 4.32 & 88.44 \\
\hline & Pectinidens diaphanum & 0.52 & 0.53 & 3.46 & 91.9 \\
\hline \multirow{4}{*}{480} & Hyalella sp. & 4.3 & 4.7 & 49.67 & 49.67 \\
\hline & Oligo-morph1 & 2.52 & 2.27 & 24.68 & 74.35 \\
\hline & Lancetes angusticollis & 1.51 & 1.2 & 13.16 & 87.51 \\
\hline & Chiro-morph1 & 1.06 & 0.67 & 5.4 & 92.92 \\
\hline \multirow{2}{*}{700} & Hyalella sp. & 4.52 & 3.37 & 78.22 & 78.22 \\
\hline & Oligo-morph1 & 1.33 & 1.31 & 14.8 & 93.01 \\
\hline
\end{tabular}

1 


\section{Table 5 (on next page)}

Sub-Antarctic freshwater macroinvertebrates functional feeding groups.

Similarity Percentages (SIMPER) analysis of freshwater macroinvertebrate functional feeding groups composition that contribute approximately $90 \%$ of the abundance of the assemblage from sampling sites of the Róbalo river watershed, Navarino Island, Chile. Abreviations, FFG $=$ Functional feeding groups, Av. Abund. Average Abundance, Sim/SD= Similarity Standard Deviation, Contrib. $=$ Contribution, Cum $=$ Cumulative, $\mathrm{C}-\mathrm{G}=$ collector gatherers, $\mathrm{C}$-fil $=$ collector filterers, $\mathrm{C}$-pred $=$ collector predators, Herb $=$ herbivores, Pred $=$ predators. 


\begin{tabular}{cccccc}
\hline $\begin{array}{c}\text { Elevation } \\
\text { (m.a.s.l.) }\end{array}$ & FFG & Av. Abund. & Sim/SD & Contrib. \% & Cum. \% \\
\hline \multirow{2}{*}{20} & C-G & 5.71 & 7.55 & 48.67 & 48.67 \\
& Pred & 2.86 & 8.00 & 24.53 & 73.2 \\
& Herb & 2.06 & 1.65 & 12.64 & 85.84 \\
& C-pred & 1.93 & 1.13 & 9.30 & 95.14 \\
\hline \multirow{2}{*}{250} & C-G & 2.98 & 3.5 & 55.91 & 55.91 \\
& Pred & 1.57 & 1.56 & 21.52 & 77.43 \\
& Herb & 1.23 & 0.96 & 14.04 & 91.47 \\
\hline \multirow{2}{*}{480} & C-G & 4.56 & 5.28 & 71.94 & 71.94 \\
& Pred & 1.84 & 1.74 & 23.49 & 95.43 \\
\hline
\end{tabular}

1 